\title{
PSYCHOLOGICAL AND SOCIOLOGICAL ASPECTS PREVENTING "COMMON WALLET" PERCEPTION IN THE PUBLIC BUDGET
}

\author{
Fidan KILAVUZ ${ }^{1}$
}

\author{
Cihan YÜKSEL ${ }^{2}$
}

\begin{abstract}
This study mentions the perception of "common wallet" and the determining phases of shaping process, in order to scrutinize the way Society's perception has got its background using sociological and psychological parameters. What "common wallet" means is the public budget which is the legitimate source that enables the government to spend and gather resources. Understanding of public budget is closely related to social interactions between citizens, their behaviours and acts since it is a product of labour productivity. Thus, since the budget rights starting point is the citizen's common money; it is based on the need to identifying common (social) need from this budget.

On the other hand humans are described as social entities firstly. Humans effect the society they live in and they get effected by the society as a reason for that. Because of these, social interaction as an individual and as a group effects what we can identify as a social common value "common wallet" perception and the shaping process. Based on this perspective "common wallet" perception and determinants of the shaping process are examined via social psychology perspective; while the concepts of altruism, altruistic punishment, lack of social belonging, bystander effect, social loafing, cognitive contradiction theory and ethical behaviors/cultural behaviors were utilized, the public budget consciousness shaped within this social relations was tried put forwards.
\end{abstract}

From this point of view it is aimed to contribute to the problem from a wider perspective and to provide constructive solutions.

Keywords: Public Budget, Common Wallet, Fiscal Sociology.

JEL Code: H31, H61.

\section{Introduction}

Public expenditures made by the state express the common expenditures of the society. Financing of these services that the state provides is realized by collecting some income from the society, taxes coming in first. Thus, the public budget which is the legitimate instrument for the government to make common expenditures and gather common incomes is actually the common wallet for all the citizens living in that country. The biggest support for this is that the expenses made in order to meet the expenses of the citizens living in that country are being made from this wallet (public budget). Therefore, as well as there is individual budgets (wallets) exists public budget is actually means the common budget (wallet) of the community. In this study what we mean by "common wallet" is actually the public budget itself with this perspective. What we want to tell with the "common wallet" perception which is the main focus of this study is the insensitivity of the people to extravagant use of budget resources which is produced by with their own labor productivity. In the first chapter of this study with the perspective aforementioned, we discussed the "common wallet" perception in the public budget.

1 Graduate Student, Mersin University, Department of Public Finance, klavuzfidan@yahoo.com

2 Asst. Prof. Dr., Mersin University, Department of Public Finance, cihanyuksel@mersin.edu.tr 


\section{2. "Common wallet" perception in the public budget}

Public budget is a concept which needs to be discussed and is worth-stressing about because with the effects of structural differences in the social layers of society, public budget is being perceived differently.

\subsection{Concept of "Common Wallet"}

State takes care of common needs while making public expenditures and obtains the public revenues in order to be able make these expenditures. Goods and services required for the presentation of public services are purchased and expenses are converted into public service by means of the revenues gathered. Therefore, we can state the public budget which is the sum of the expenditures made to meet the common needs of society and the revenues obtained to provide the financing of these expenditures, we can refer to a common wallet used for the common needs of society. An important aspect in this point is that this wallet is financed by the citizens and is also spent on providing services to the citizens. This situation points to one of the important points where the common wallet (public budget) differs from the personal wallets (budgets) of micro economic actors. In our study we preferred to express the public budget as "common wallet", as a metaphor tool based on these differences. At this point we can define the concept of common wallet as:" Public source that shows citizens' common incomes and common expenses in detail and collects incomes for the common interests of the society and authorizes the realization of expenses".

On the other hand it is very important to evaluate the concept of common wallet on all dimensions which undergoes development and change in strict adherence to social dynamics. At this point the perception of the common wallet by the citizens appears as an element to be emphasized. In the next section "Common Wallet" will be discussed as the weakening of "common wallet" perception which we have explained in the subheading.

\subsection{The Weakening of "Common Wallet" Perception}

The concept of "common wallet" which we have used through metaphor cannot be clearly understood due to some problems even though it exists in practice. At the beginning of these problems the real owners of the resources that make up this wallet are not aware of the fact that they are the owners of this wallet or that this consciousness is weak. At this point weakness or the weakening of the perception will cause problems such as lack of correct use of resources, loss of social awareness and consciousness and disruption of audit process.

The fact that citizens do not show their interest in their personal wallets against the public budget, which is their common wallet, is an important factor in the development of this perception. Therefore, it is not possible to reflect the social demands in public decision-making mechanism under these circumstances.

Given the fact that budget has political, economic, financial and legal consequences it is clear how important it is accurate and effective usage. In this context it is required to search for an answer the question of "Why the sensitivity of the citizen to his personal wallet does not show if the public resources if the public resources are not used correctly and effectively". At this 
point there are many elements that causes the weakening of the common wallet perception. We can list these elements as law insecurity, corruption, media-commerce-state relationship, the effect of liberal thought, the structure of nongovernmental organizations, lack of public consciousness, weakness of citizenship consciousness, role of education, psychological and sociological elements. But we have evaluated the psychological and sociological aspects on this study of ours.

\section{Psychological and Sociological Aspects Preventing "Common Wallet" Perception}

The system of mainstream thinking defines individuals as homeconomicus. In other words, according to basic the basic assumption of classical and neo-classical economics individuals are rational and selfish. Therefore, individuals do not reflect their mood emotions and behaviours as they are rational in their decisions and preferences. But people are so versatile that they cannot fit into such narrow molds. As a matter of fact, humans are social creatures that affect the society and get affected by society. Thus, humans are open to social interaction. This social interaction affects humans' acts and behaviours. This is the reason why people act similarly, influenced by each other despite their personal differences. This situation affects the political, social and economic motives. Therefore, it would be appropriate to take advantage of some sociological and psychological concepts in explaining the formation and development process of public wallet perception that is intertwined with the society.

Actually this part of our study is in the scope of behavioural economics which is a separate field of study. Thus, behavioural economics is an area that observes the effects of the attitudes, behaviours and thoughts of people forming the common point of action of psychology and economics on economics-based choices and decisions and examines these observations based on experiments (Toigonbaeva \& Eser, 2011:288). Thereby when we study the weakening of individuals perspective on common wallet perception within the framework of behavioural economics the following concepts emerge.

\subsection{Lack of Social Belonging}

People have moved away from social integration with the strengthening of the institutional structures shaped within the framework of metamorphisms and transformations in today's conditions. Especially with the emergence of individualization after the 1980 s accelerated this process.

On the other hand, with the discourse of "modern people" social structures have lost their meaning and reality and under these conditions people have been under the influence of sudden and transient popular culture. Man, has become an expert in the means of consumption patterns determined under these conditions. It is the reason why men are alienated from themselves and the society (Zijderveld, 1985: 137). Alienation leads to the weakening of the social ties of people with "weakness" and "nonsense" dimensions.

It is a unchangeable reality that the mechanism of public administration cannot be considered separately from social processes and formations. In this context, it is very difficult to create or perceive common values in social structures where social perceptions cannot be fed. These forms of formation lead to remaining weak or weakening of the common wallet perception 
created by the common contributions of the society. Because this situation will also give rise to a social weakness in which social empathy is weak in society, individualization is strengthened and alienation increasing.

\subsection{Altruistic Punishment}

Altruistic punishment means that individuals will punish other individuals even if they know that the results might lead to any negativity for the group they are in or for themselves and they know that this will not give them any material interest. (Fehr \& Gächter, 2002: 137).

In addition, altruistic punishment is one of the indicators of the importance of protecting the behavioural forms of justice in social groups. In this context we can say that social preferences too are important for people besides economic preferences (Barclay, 2006: 342). Therefore, it will not be wrong to say that collective actions can be kept under control by altruistic forms of action.

Reaction or punishment by the members of the same group to the part of the group that causes damage to the social group will create an internal control mechanism. However, the person who reacts against to the damage that has occurred must also take the risk to face a reaction or exclusion. The large scale of reaction and probable exclusion of these people often condemns the society to be unresponsive. In this context the society will be unresponsive to the unlawfulness, corruption and injustice that will be experienced in the political, social and economic areas of social structures where altruistic punishment is weak. On the other hand, in social structures where social responsibility and integration are not developed individuals can act so that they do not contradict group norms. In other words, people do now exhibit behavior contrary to the group without adopting social common values. In this case, people will continue to exhibit the same behavior in areas where they will not be subjected to reaction or punishment. It is the reason it is important that people adopt social common values. In this context, it is important to adopt the common wallet which we can characterize as one of the common values of the society as a common value. Hence, these factors play a decisive role in the development or the weakness of common wallet perception.

\subsection{Bystander Effect}

Bystander effect is a concept that states that people feel less responsible as the number of people who notice the event increases and therefore they expect others to intervene (Hudson \& Bruckman, 2004: 169). In other words, the response of the people to the events that occur is inversely proportional to the number of group members (Fredricks, Ramsey \& Hornett, 2011: 4). Bystander effect is also called the spectator effect or the disinterest in the audience.

Social pressures, pluralistic ignorance, responsibility dissemination or sharing, the desire to protect himself by thinking that his security will be endangered, to think that the person does not have enough skills, the complexity of the situation is considered to be among the reasons for the disinterest in the audience (Özdevecioğlu, Kaya \& Dedeoğlu, 2014: 28; Grantham, 2011: 264).

We can say that psychologically-based spectator disinterest affects people's perception of common wallets in the context of public budget.As a matter of fact, citizens may think that the decisions taken or the expenditures made on public budget are already followed by another 
person or that they will react to any negativity.In other words, citizens will move away from the perception of common wallets with the idea that the responsibility is shared within the community.

\subsection{Social Loafing}

Social loafing is a tendency for individuals to be less productive or less likely to struggle in comparison to others who perform the same task within the group (Harcum ve Badura, 1990: 629). Social loafing occurs consciously or unconsciously, due to a decrease in social awareness individual shows less effort in the group than if they were to be alone. (Liden, Wayne, Jaworski \& Bennett, 2004: 286).

We can say that some citizens exhibit social loafing behavior in the pursuit of the common wallet created with common contributions. Although individuals contribute to the formation process of the common wallet they may choose to spend less effort for the reasons underlying social loafing behavior in order to act in line with social goals. This situation is observed more frequently in social structures where social integration and common values do not occur.

\subsection{Cognitive Contradiction Theory}

The theory of cognitive contradiction presented by Leon Festinger in 1957 refers to the situation in which one's knowledge, belief or attitude contradicts another knowledge, belief or attitude of the same person (Festinger, 1957: 177-179). This is in fact an individual developing a psychological defence mechanism.

On the other hand, cognitive contradiction is also discussed within the framework of obedience and acceptance mechanisms. As a matter of fact, people exhibit compliance behaviour when faced with external pressure, punishment or coercion. But these behaviours do not reflect their true attitude. But if a person really does something right within himself or because he has found the behaviour of a group to be correct,then as in the case in adoption, person's own behaviour will also reflect the attitude (Kağıtçıbaşı \& Cemalcılar, 2014: 172-173). The cognitive contradiction theory is being used in many different disciplines is a theory we can also use in finance to explain why the citizens are unresponsive or insensitive to corruption and against the effective use of the common wallet.

\subsection{The Underdevelopment of Ethical Behavior/Culture}

Issues related to what is good or true for people and social structures fall within the scope of their ethical behavior/culture. Public administration ethics is the shaping of behaviors of employees within a certain organizational structure within the framework of defined laws, ethical codes and various rules (Özdemir, 2008: 182).

While the lack of ethical consciousness and culture causes corruption and unethical behaviors in the society, these negativities are also reflected in the public administration process as they are reflected in other social fields. Especially, the fact that public officials are not only responsible for the organizational structure they work in and that they are responsible for the citizens also increases the importance of ethical behaviors that will be adopted in public spaces. 
On the other hand, the differences in what is good or true are evaluated within the framework of ethical theories.Thus, it is important whether the ethical approach we adopted in the ethical context is a pragmatic understanding of ethics or a principled moral understanding (Haşlak, 2006: 186-187).

\section{Conclusion}

The public budget, which we call the common wallet, is simply the common money of the citizen.For this reason, public (common) needs are identified and met by this budget. One of the main reasons why state exists is that it fulfils these social needs in a way that increases the public benefit without profit.As a matter of fact, since public goods and services cannot be priced, this situation also contradicts with the fundamental mechanism of the private sector acting with profit motives.

The concept of public administration, the formation and development processes of public budget consciousness are closely related to the elements shaping the social structure.While the elements we considered in our study guided us to make sense of the individual - society dynamics, it made it easier for us to evaluate the factors affecting the common wallet and common wallet perception that we have defined as a common value. As a matter of fact, the individual shaped by these sociological and psychological factors that affects the social behaviours of people due to the social impact is a part of the social structure. Hence, the mechanisms that constitute the social behaviours play important roles in social structures. The psycho social factors that will enable citizens to have the budget right or to prevent them from seeking this right also form the framework of social structures.

\section{References}

Barclay, P. (2006). "Reputational Benefits for Altruistic Punishment", Evolution and Human Behavior, 27 (5), pp. 325-344.

Fehr, E., \& Gächter, S. (2002). "Altruistic Punishment in Humans", Nature, 415 (6868), pp. 137-140.

Festinger, L. (1957). A Theory of Cognitive Dissonance, 2, California, Stanford University Press.

Fredricks, S., Ramsey, M. \& Hornett, A. (2011). "Kinship and Bystander Effect: The Role of Others in Ethical Decisions", Journal of Religion and Business Ethics, 2 (1), pp. 2-22.

Grantham, T. C. (2011). “New Directions for Gifted Black Males Suffering from Bystander Effects: A Call for Upstanders", Roeper Review, 33 (4), pp. 263-272.

Haşlak, I. (2006). "Etik Kongresinin Ardından”, Akademik Incelemeler Dergisi (AID), 1 (1), ss. 185-192.

Hudson, J. M. \& Bruckman, A. S. (2004). "The Bystander Effect: A Lens for Understanding Patterns of Participation", The Journal of the Learning Sciences, 13 (2), pp. 165-195.

Kağıtçıbaşı, Ç. \& Cemalcılar, Z. (2014). Dünden Bugüne Insan ve Insanlar: Sosyal Psikolojiye Giriş, 16. Baskı, İstanbul, Evrim Yayınevi. 
Liden, R. C., Wayne, S. J., Jaworski, R. A. \& Bennett, N. (2004). "Social Loafing: A Field Investigation", Journal of Management, 30 (2), pp. 285-304.

Özdemir, M. (2012). "Kamu Yönetiminde Etik", Uluslararası Yönetim iktisat ve Işletme Dergisi, 4 (7), ss. 177-193.

Özdevecioğlu, M., Kaya, Y. \& Dedeoğlu, T. (2014). “Kişilik Özelliklerinin İzleyici Etkisi (Bystander Effect) Üzerindeki Etkisinde Kontrol Odağinin Rolü", Erciyes Üniversitesi iktisadi ve Idari Bilimler Fakültesi Dergisi, 42, ss. 25-40.

Seeman, M. (1959). "On the Meaning of Alienation”, American Sociological Review, 24 (6), pp. 783-791.

Toigonbaeva, D., \& Eser, R. (2011). "Psikoloji ve İktisadın Birleşimi Olarak, Davranışsal íktisat", Eskişehir Osmangazi Üniversitesi Iktisadi ve Idari Bilimler Fakültesi Dergisi, 6 (1), ss. 287-321.

Zijderveld, A. C. (1985). Soyut Toplum, (Çev: Cevdet Cerit), İstanbul, Pınar Yayınları. 